\title{
以学生为主体的小学语文教学方法多样化探究
}

韦华 ${ }^{1}$ 李春羚 $^{2}$ 黄瑛 $^{3}$

1 广西省河池市巴马瑶族自治县巴马镇中心小学 2 广西省河池市巴马瑶族自治县巴马镇巴马村小学

3 广西省巴马瑶族自治县巴马镇中心小学

DOI:10.32629/jief.v2i9.1712

[摘 要] 在应试教育模式影响下, 教师中心论妨碍了学生创新精神和创新能力的培养, “逼迫教育、填鸭式的教学、负担教学、淘汰教学” 等成为教师单向灌输知识的教学模式, 以考试分数作为衡量教学质量的唯一标准及过于呆板的教育教学制度, 最终导致教学陷入 “学服从于 教、教服从于考” 的状态。学生的智力潜能得不到应有的开发，情感意志得不到积极的陶冶锻炼，个性特长得不到充分的培养，主动性、创 造性得不到应有的发挥。

[关键词] 小学语文; 教学方法; 多样化

中图分类号：G623 文献标识码：A

\section{1 课题提出的背景}

江泽民同志在第三次全国教育工作会议上指出: “必须转变那种妨碍 学生创新精神和创新能力发展的教育观念、教育模式, 特别是由教师单 向灌输知识, 以考试分数作为衡量教学质量的唯一标准, 以及过于呆板 的教育教学制度”。目前, 基础教育改革正以世人瞩目的迅猛之势在全国 顺利推进, 它将实现我国中小学课程从学科本位、知识本位向关注每一 个学生发展的历史性改变, 它的主要任务是培养全体学生的基础素质, 培养他们的自主性、能动性和创造性, 为他们主动学习和终身发展打好 基础, 为优化民族整体素质打好基础。本课题研究的目的在于树立起学 生为主体的教育观, 因材施教, 以学定教, 尊重学生的主体地位, 注重 唤醒学生的主体意识, 培养学生的主体能力, 塑造学生的主体个性, 充 分调动学生学习的积极性和创造性, 促使学生活泼主动、和谐发展。

新改革对教师的教学行为提出了更高的要求, 它要求教师在全新的 理念指导下, 充分利用各种教育资源, 实现各种教育资源的整合, 以全 面提高教育教学效益, 最终达到全面提高教育教学质量的目的。小学语 文教学的最终目的是培养学生的语文素质, 在教学中, 注重学生语文能 力的训练与培养, 利用教材优势给学生创造更广阔的语言交际环境, 以 识字和发展语言同步为目的, 进行全方位、多角度的训练。这样设计完 全符合语文课程标准的要求, 而且达到了语文课程标准的上限的要求。 如何让学生在原本枯燥的教学中学得更有趣、主动, 记得更牢固、扎实, 营造氛围、教给方法、转变观念是及其重要的。

\section{2 课题研究的指导思想和理论依据}

2.1 指导思想

以马列主义、毛泽东思想为指导，以建设有中国特色的社会主义理 论为指针, 以党的教育方针政策为方向, 以科学理论为基础对课堂学习 方式进行探究, 从而提高教学质量, 培养学生自主学习的能力。

2.2 理论依据

（1）根据辨证唯物主义理论的认识论, 体现: 实践一认识一在实践 一再认识的认识过程。(2) 根据素质教育的体制要求, 培养学生对未 来社会的适应能力, 学会学习, 学会探究, 学会与人合作。(3) 根据儿 童身心发展规律, 个体差异和不同的学习需要。

\section{3 课题研究内容}

3.1 研究以学生为主体的小学语文教学中如何体现多样化以及多样 化的作业设计的意义。

3.2 研究以学生为主体的小学语文多样化学习方法、学习兴趣、学 习成绩的影响。

3.3 研究以学生为主体的小学语文教学多样化对小学生的学习习惯 形成的帮助, 以及对于学生潜能发挥的影响。

\section{4 研究方法}

4.1 文献资料法: 通过查阅文献资料论证本课题研究的可行性, 为 本课题的研究提供引导性理论, 并及时了解当前国内外同一课题研究的 进展情况, 不断总结研究的成果。

4.2 行动研究法: 讲教学实践与研究工作相结合。通过运用实践、 问卷、访谈、查证等科学方式, 有目的、有计划、有系统地开展调查与
分析。

4. 3 案例分析法: 将行动研究法应用在本课题课堂教学研究之中, 及时进行案例分析, 及时调整研究行为, 并使阶段研究成果更为科学。

4. 4 经验总结法: 将经验总结法贯穿在本课题研究的整个过程中, 及时进行反思和总结, 积极撰写课题研究文章, 促进课题研究成果的不 断凸现。

\section{5 主要研究阶段}

5. 1 准备阶段（2019.5一-2019.6）

5.1 .1 课题准备。做好确立、论证等前期准备工作, 制定研究实施 方案。

5.1 .2 了解学生的状况, 完成调查报告, 确定实验班级, 明确实验 目标。

5.1 .3 查阅文献, 认真学习有教育理论和教育科研方法。

5.2 实施阶段（2019.7-—2020.4）

5.2.1 根据实际教学情况, 寻找教研工作的最佳切入点。

5.2.2 运用各种研究方法积累相关资料, 收集典型材料, 作出分析, 总结经验。

5.2.3 继续学习理论知识, 积累资料, 并且有针对性地进行全面探 索与实践。

5.2.4 学习理论知识并运用有关理论知识指导实践, 分析实验过程 及时撰写研究论文。

5.2 .5 观察实验效果, 做好效果测定和阶段性总结。

5.3 总结阶段（2020.5一-2020.6）

5. 3. 1 将研究取得的成果做成统计分析, 整理数据、撰写研究报告。

5.3.2 完成课题研究性报告。

5.3. 3 汇编课题研究成果专集。成果形式：论文集、影像等资料。

5.3. 4 申请结题, 推广实验成果。

\section{6 完成课题的可行性分析}

课题组全体成员对课题有很高的积极性, 参与意识很强, 且有较扎 实的业务知识, 有较高的理论水平和研究水平, 有较强的组织能力和观 察能力。在时间保证方面, 英语教师能经常深入班级调查研究, 有时间 进行课题研究。本课题资料储备较多, 资料查找也很方便。本校研究的 成果及各种信息资料也能保证及时收集、及时分析、及时定论、及时存 档。课题组人员分工科学合理：韦华负责资料的分析、论证和指导整个 科研的工作; 李春羚、黄瑛负责实验阶段资料的收集、信息的分析; 课 题组所有的老师负责课题的实验, 提供实验中的所有数据和信息。

\section{[参考文献]}

[1]于雪. 思维导图在小学低年级古诗教学中的应用研究[D].喀什大 学,2019.

[2]季彦辛.思维导图在小学语文阅读教学中的应用[J].西部素质教 育,2018,4(13):242

[3]贺菊.思维导图在小学语文教学中的实践运用 [J].甘肃教 育,2017(08):79 